\title{
Infectious Complications in Severely Burned Adult Patients-Diagnostic and Therapeutic Algorithm
}

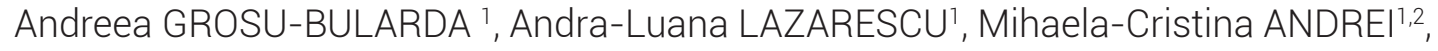 \\ Dan Aurel IONESCU ${ }^{1}$, Adrian FRUNZA ${ }^{1,2}$, Sabina GRAMA ${ }^{1}$, Alexandru STOIAN ${ }^{1}$, Florin Vlad HODEA ${ }^{1}$, \\ Tiberiu Paul NEAGU ${ }^{1,2}$, Serban ARGHIR POPESCU1,2, Ioan LASCAR ${ }^{1,2}$
}

\begin{abstract}
Severe burn injuries represent a major challenge to the entire healthcare system in developing countries and even for states with a high standard of care. A clear understanding of the physiopathology of burn injuries is essential for providing an adequate prompt treatment to ensure an optimal patient outcome. Early recognition and treatment of burns complications, especially severe infections represent an important prevention strategy, improving survival after these severe injuries. Specific treatment must be conducted according to the characteristics of the patients in order to reduce morbidity and mortality and avoid the development of antimicrobial resistance. A diagnostic and therapeutic algorithm is presented, centered on infectious source prevention and control with early surgical excision and skin grafting together with culture-guided antimicrobial therapy. It is a known fact that, indifferent of the involved germ, the best intervention for both prophylaxis and treatment of infections in the burn patient is the early excision of the devitalized tissue and subsequent closure of burn wounds with skin grafts, measures that diminish local and systemic mediator releasing effects in burnt tissue, attenuating the progressive inflammatory chain.
\end{abstract}

Keywords: Severe burns; infection; complications; sepsis; early excision and grafting; antibiotic resistance; algorithm.

\section{Rezumat}

Leziunile postcombustionale severe reprezintă o problemă majoră de sănătate publică, atât în statele în curs de dezvoltare cât și în cele cu un sistem de sănătate avansat. Este necesară o bună cunoaștere a fiziopatologiei arsurilor pentru a acorda pacientului un tratament ce asigură rezultate optime în ceea ce privește prognosticul vital și funcțional. Recunoașterea precoce și tratamentul complicațiilor arsurilor, mai ales al infecțiilor severe, reprezintă o strategie importantă de prevenție, îmbunătățind rata de supraviețuire după astfel de traumatisme. Tratamentul specific trebuie adaptat în funcție de caracteristicile fiecărui pacient pentru a reduce morbiditatea și mortalitatea și a evita dezvoltarea rezistenței antimicrobiene. În urma analizei literaturii de specialitate, propunem un algoritm diagnostic și terapeutic al complicațiilor infecțioase în arsurile severe, centrat pe măsuri preventive și management adecvat al pacientului ars pe perioada spitalizării, elementele de bază fiind excizia agresivă a țesuturilor devitalizate și acoperirea plăgilor arse cât și antibioterapia ghidată de rezultatele culturilor și antibiogramei. S-a constatat că indiferent de agentul patogen implicat, atât pentru profilaxia cât și pentru tratamentul infecțiilor la pacientul ars, o măsură esențială este excizia precoce a leziunilor postcombustionale profunde și grefarea defectelor rezultate, astfel reducându-se eliberarea de mediatori inflamatori local și sistemic și atenuând cascada inflamatorie progresivă.

Cuvinte cheie: arsuri severe, infecții, complicații, sepsis, excizie precoce și grefare, rezistență antibiotică, algoritm.

${ }^{1}$ Clinic of Plastic Surgery, Aesthetic and Reconstructive Microsurgery, Emergency Clinical Hospital, Bucharest, Romania

2 "Carol Davila" University of Medicine and Pharmacy, Bucharest, Romania

\section{Corresponding author:}

Andra-Luana LAZARESCU, Emergency Clinical Hospital,

$8^{\text {th }}$ Calea Floreasca, Bucharest, Romania.

E-mail: luana.lazarescu@gmail.com 


\section{INTRODUCTION}

Major burn injuries represent a significant problem around the world, being associated with high morbidity and mortality, poor social rehabilitation, and increased healthcare costs ${ }^{1,2}$.

Due to the complex nature of their injuries, patients suffering severe burns require prompt intervention and initialization of specific, integrative treatment in a dedicated burn unit with a multidisciplinary team ${ }^{3}$.

Patients with burn injuries should be transferred to a burn unit if any of the following criteria is present ${ }^{4}$ :

- Partial thickness burns on more than 10\% TBSA (total body surface area);

- Presence of third-degree burns;

- Burns affecting functional areas(face, hands, feet, major joints, perineum, genitalia);

- Chemical or electrical burns;

- Inhalation injury;

- Concomitant trauma associated to burn injury;

- Preexistent comorbidities;

- Pediatric patients(referred to dedicated burn centers);

- Burn injury in patients requiring special rehabilitation, social or emotional support.

Three evolutive phases are recognized in major burns evolution ${ }^{5-7}$ :

- Emergency phase( first 48-72 hours after occurrence of the burn injury); adequate fluid resuscitation is mandatory in this phase;

- Acute phase: from 48-72 hours until complete burn wound coverage; in this hypermetabolic stage it is essential to prevent systemic and local complications, especially infections;

- Rehabilitation phase-extends long term after hospital discharge; sustained rehabilitation programs are needed for physical recovery and social reintegration.

It is very important to carefully monitor the burn patient through his entire course during the above-mentioned phases in order to early recognize the complications that may lead to increased morbidity and mortality and subsequently apply the specific therapeutic measures ${ }^{1,7}$. A major preoccupation is to identify and avoid the conditions that trigger the onset of organ dysfunction. Early excision of deep, full-thickness burns and wound coverage, adequate local treatment along with systemic support play a major role in decreasing complications and improving final functional outcome of severely burned patient $t^{1,6,8}$.
Infections are most frequently encountered and also most severe complications in burned patients, the development of sepsis leading to increased mortality rates. According to international reports, infectious complications determine $42 \%-65 \%$ of deaths in burned patients; also, the mortality rate of infected burn patients is twice higher than mortality of patients unaffected by infectious complications ${ }^{9,10}$. Therefore, development of diagnostic and therapeutic protocols of infectious complications are mandatory in this field, a particular aspect being the necessity to adapt those findings to each burn unit, oriented to specific pathogens and local efficient antibiograms ${ }^{9}$.

\section{METHOD}

The analysis of recent relevant data from international literature was performed and corroborated with our clinical experience in severe burn injuries, in order to elaborate a comprehensive algorithm that could guide the therapeutic team in management of infectious complications in major burns, the goal being obtaining an optimal functional outcome and reducing morbidity and mortality of these patients.

\section{RESULTS}

We propose the following algorithm as a guide for burn infections management in the burn units. This algorithm encompasses the prevention, diagnosis and treatment of infectious complications in the burn patients throughout their hospitalization, following the particularities of each evolutive phase of burn injury and trying to address the challenges encountered by the clinician:

Diagnostic and therapeutic algorithm of infectious complications in severely burned adult patients:

\section{INITIAL HOSPITAL MANAGEMENT OF MAJOR BURNS ${ }^{11-16}$ :}

- Life support: ABCDE approach: Airway, Breathing, Circulation, Disability, Exposure;

- Installation: intravenous lines, Foley catheter, nasogastric tube;

- Starting fluid resuscitation as soon as possible;

- External warming, warm fluids, analgesics;

- Burn wound cleaning;

- Tetanus immunization; 
- Transfer the patient to dedicated Burn Unit as soon as possible ( $<8$ hours)!

- Interdisciplinary systemic evaluation of the patient;

- Burn wounds assessment: experienced plastic surgeon!

- Blood tests, imagistic evaluation;

- Microbiological screening on admission in the Burn Unit: swabs from conjunctiva and external ear, nasal exudate, pharyngeal exudate; at least 2 probes/situs from the burned wound (from different areas), and for extensive burns- sampling from several interested lesions, with the exact specification of the tested areas; tests from unburned areas (groin, axillary regions), tracheal probe if necessary, uroculture, rectal swab.

\section{THERAPEUTIC STRATEGY DURING BURN UNIT HOSPITALIZATION:}

\section{Moment of admission: Identify severity factors ${ }^{17-21}$ !}

- Patient-related factors:

- Extreme age-pediatric or elderly patients;

- Existent comorbidities: cardiac, pulmonary, hepatic, renal, diabetes, autoimmune disorders;

- Acute intoxications-alcohol, drugs;

- Dehydration;

- Psycho-social factors: psychiatric disorders, aggression, social cases.

- Lesion-related factors:

- Extensive burns;

- Deep-IIB degree or full thickness burns;

- Electrical injuries;

- Chemical burns;

- Inhalation injury;

- Cyanide intoxication;

- Concomitant trauma associated to burn lesion, internal lesions.

- Innapropriate therapeutic management:

- Delay in initiation of fluid resuscitation;

- Inadequate fluid resuscitation;

- Complications of fluid resuscitation;

- Other initial complications: on catheters installation, aspiration.

\section{EMERGENCY PHASE}

From the moment of injury until the complete fluid resuscitation (the first 48-72 hours)

Following measures are applied 1,7,16,22-25:

- Prevention of burn shock and management of fluid loss is critical: early and correct fluid resuscitation is essential!

Recommended: Parkland Formula: $4 \mathrm{ml}$ crystalloid solutions(Ringer lactat) $\mathrm{x} \mathrm{kg} x$ burn surface for the first 24 hours, from which half in the first 8 hours and the other half in the next 16 hours.

This formula should be taken as a guideline and adapted as needed to the hemodynamic parameters, with aim of maintaining intravascular volume for adequate tissue perfusion.

Urinary output monitorization: maintain diuresis $0,5 \mathrm{ml} / \mathrm{kgc} / \mathrm{h}$ for thermal burns and $1-2 \mathrm{ml} / \mathrm{kg} / \mathrm{h}$ for electrical injuries.

- Consider administration of colloids, high-dose vitamin C;

- Blood purification strategies may be required;

- Systemic support of the patient;

- Prevention of respiratory distress;

- Treatment of concomitant injuries;

- Wound assessment and management(Figure 1);

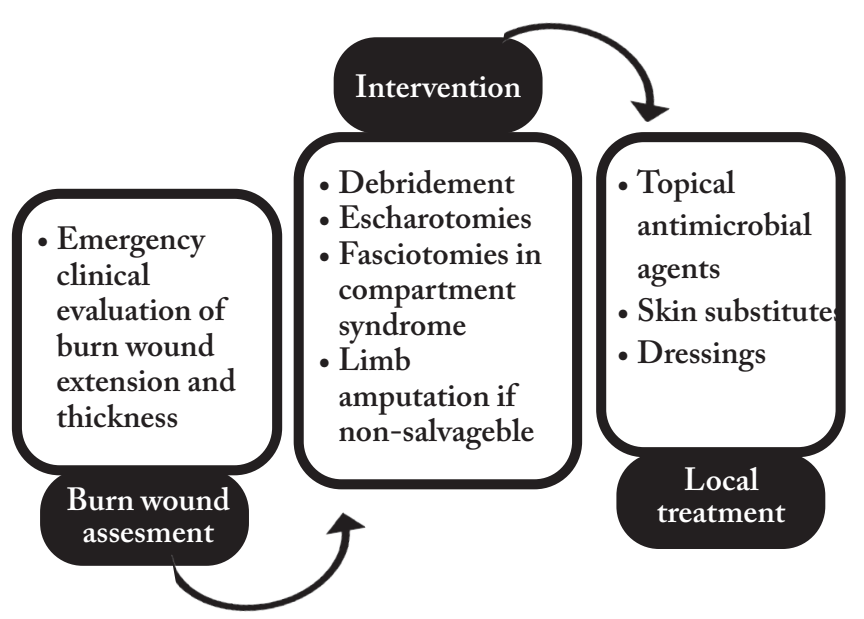

Figure 1. Wound assessment and management during emergency phase

- Inhalation injury evaluation: clinical sugestive findings-> perform bronchoscopy! (Figure 2).
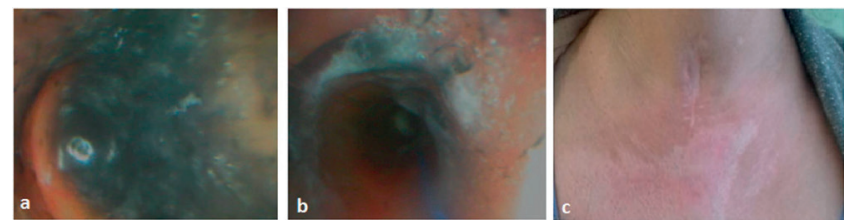

Figure 2. Airway burns bronchoscopy(a and b images) aspect in a 36-year-old female patient with 65\% TBSA after flame injury (explosion). Tracheostomy was required. The patient was discharged after 74 days of hospitalization. The last image(c) shows the tracheostomy scar at ten months follow-up. 


\section{II.ACUTE PHASE}

(after 48-72 hours until complete wound closure)

II.A. PREVENTION OF INFECTIOUS

\section{COMPLICATIONS}

General measures ${ }^{7,9,26,27}$ :

- Isolation of the burn patient in individual room;

- Strict disinfection protocols, environmental adequate cleaning;

- Hand hygiene protocols;

- Maintain adequate temperature.

Preventing of respiratory complications ${ }^{7,9,26,27}$ :

- Bronchial hygiene therapy->Removal of retained secretions!

- therapeutic coughing;

- chest physiotherapy;

- early ambulation;

- airway suctioning;

- therapeutic bronchoscopy;

- pharmacologic agents-aerosols or systemic-bronchodilators, mucolytics.

- Non-invasive ventilation;

- Tracheostomy

Advantages:

- allows maximum utilization of pulmonary reserve;

- prevents postoperative pulmonary complications.

\section{Digestive tract: maintain intestinal barrier, avoid} bacterial translocation $^{9,26}$

- Promote enteral nutrition;

- Immunonutrition;

- Selective decontamination of digestive tract.

\section{Catheters $^{9,26}$}

- Daily inspection of the catheters;

- Remove/change of colonized catheters;

- Routine change of central venous catheters is not recommended;

- Removal of the invasive devices as soon as possible when no longer needed.

\section{Burn wound management (Figure 3)-essential for} preventing complications ${ }^{28-33}$ !

- Correct diagnosis of burn lesions in order to identify deep burns requiring surgical treatment: perform clinical evaluation and also use of burn wound assessment technologies (Figures 4 and 5);

- Early excision and grafting of full thickness burns is essential(Figure 6)!

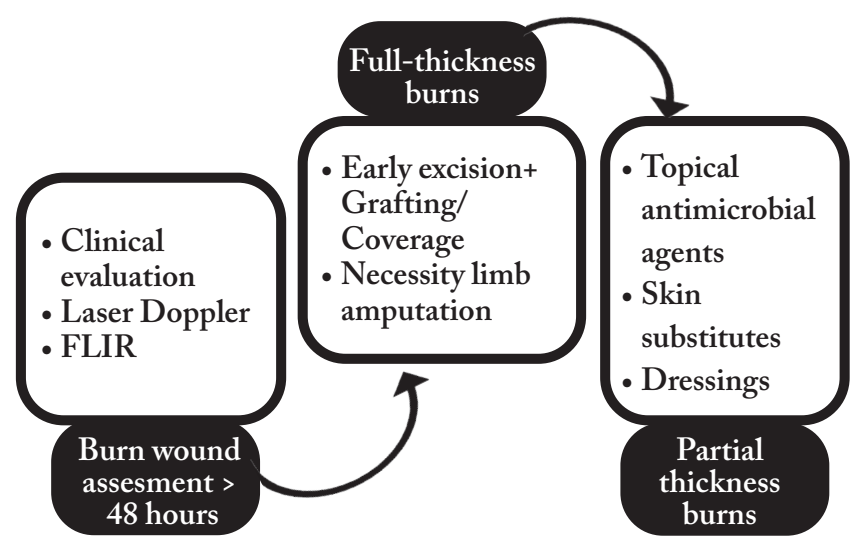

Figure 3. Burn wound management in acute phase of burn injury

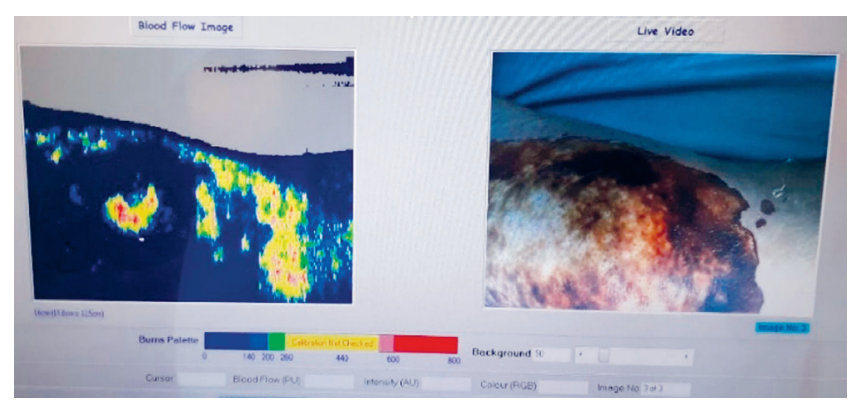

Figure 4. Laser Doppler evaluation of the burn wound
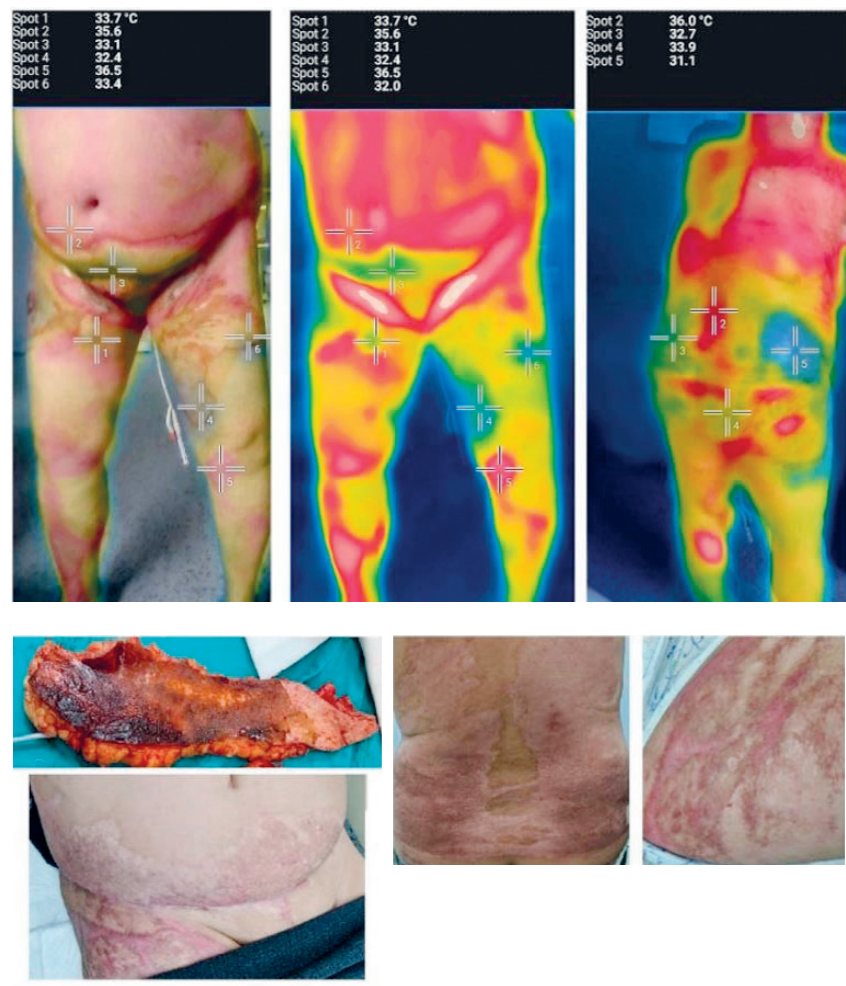

Figure 5. FLIR (forward-looking infrared camera) evaluation of the burn wounds in a 66 year old female patient with hot fluid burns on 30\% TBSA; excision and grafting was performed with good long term result 

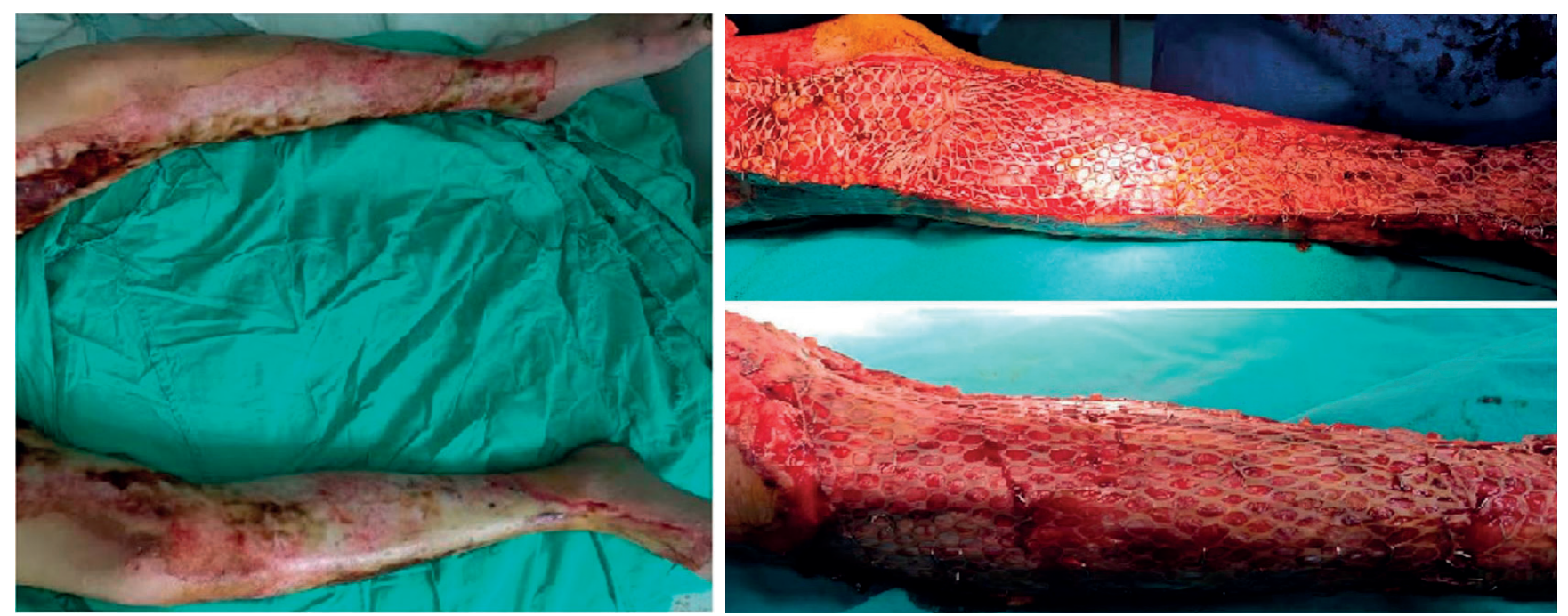

Figure 6. Full-thickness burns in an 82 year old male patient with flame burn injuries on 35\% TBSA.

Fascial excision was performed and the defect was covered with split-thickness meshed skin graft

Periocular region burns: particular region requiring careful prevention!

- Following protocol is recommended when periocular region is interested by burn lesion-Figure $7^{[34-36]}$ :

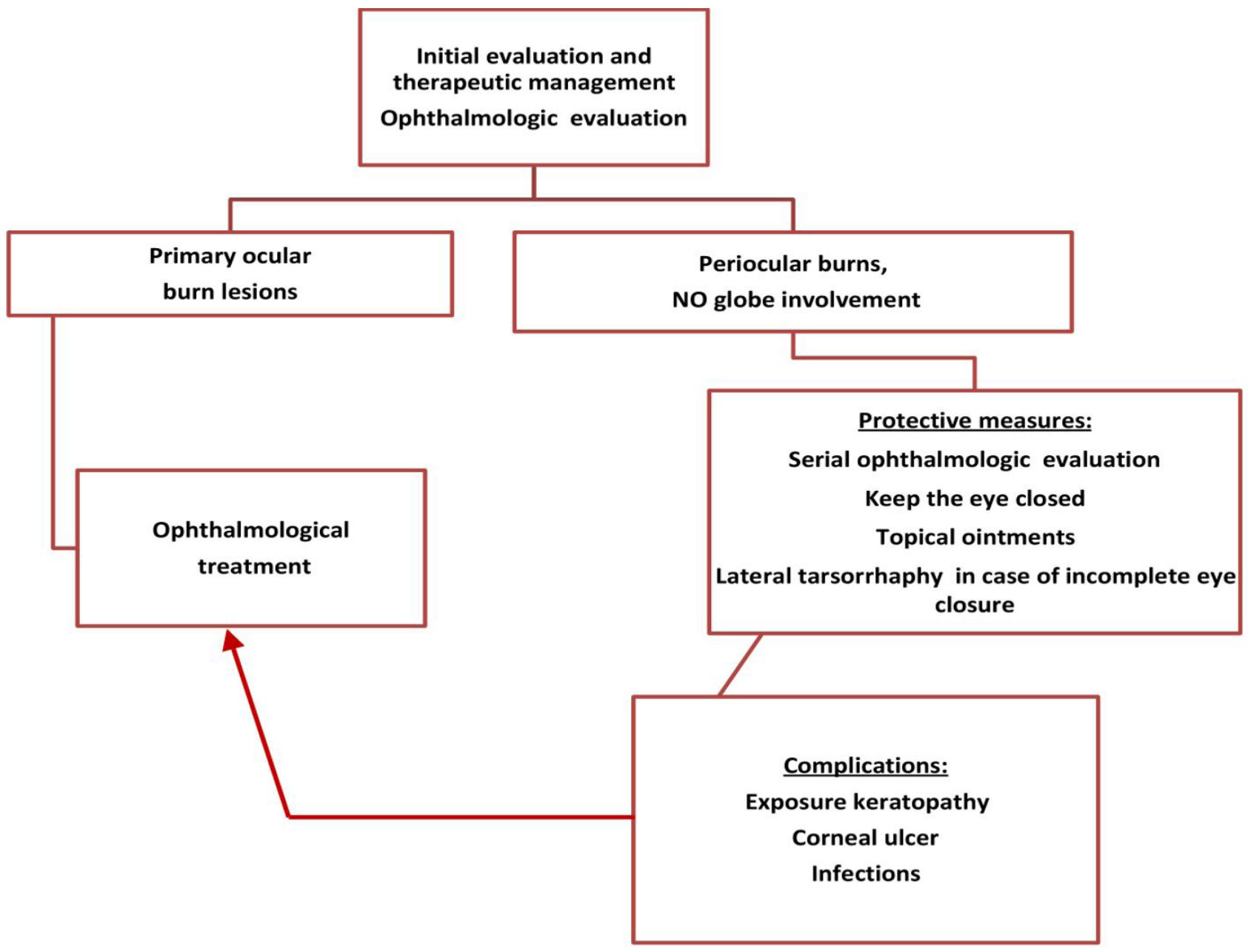

Figure 7. Management of periocular region burns 
Antimicrobial treatment in burn patient: preventive approach for improve clinical outcome ${ }^{9}$

- Avoid prophylactic use of systemic antibiotics;

- Perioperative antibiotics for surgical procedures;

- Serial screening for infectious complication detections(on admission, then weekly testing or in case of suspicion of infectious complication);

- Promote antimicrobial stewardship;

- Isolate patients with multidrug-resistant germs.

\section{II.B. DIAGNOSIS OF INFECTIOUS COMPLICATIONS}

\section{Burn wound infections}

- At each burn wound debridement and anytime there is an invasive infection suspicion, performing quantitative tissue cultures is useful ${ }^{8}$;

- Invasive skin infections of the burn wound ${ }^{26,37}$ :

- are defined as the presence of pathogens in a burn wound in high enough concentration and related to depth, surface and patient's age in order to determine the suppurative separation of the eschar or graft loss, invasion of the adjacent healthy tissues or causing a systemic response of the septic shock;

- clinically manifest by burn wound aspect, exudate, smell alteration and also the partial thickness burns patients become full thickness burns;

- The gold-standard for burn wound infection diagnostic consists of the histologic examination ${ }^{8,26}$ !

In some instances, the clinical evaluation and quantitative cultures can be enough.

\section{Respiratory infections-diagnosis ${ }^{38}$ :}

- clinical status degradation;

- change in sputum characteristics, color, amount, consistency as well as purulence;

- imagistic findings-chest radiography or computer tomography(Figure 8);

- diagnostic bronchoscopy and bronchoalveolar lavage;

- microbiologic analysis of tracheal secretion.

Gastrointestinal infections diagnosis ${ }^{26}$ :

- Clinical findings: abdominal distension, diminished bowel sounds, modified fecal with presence of mucus, blood, diarrhea;

- Fecal microbiologic analysis, test for Clostridium difficile toxins;

- Abdominal radiography: gas, air-fluid levels;

- Ultrasonography, Computer tomography;

- Pneumoperitoneum or suspected necrotic bowel: laparotomy!

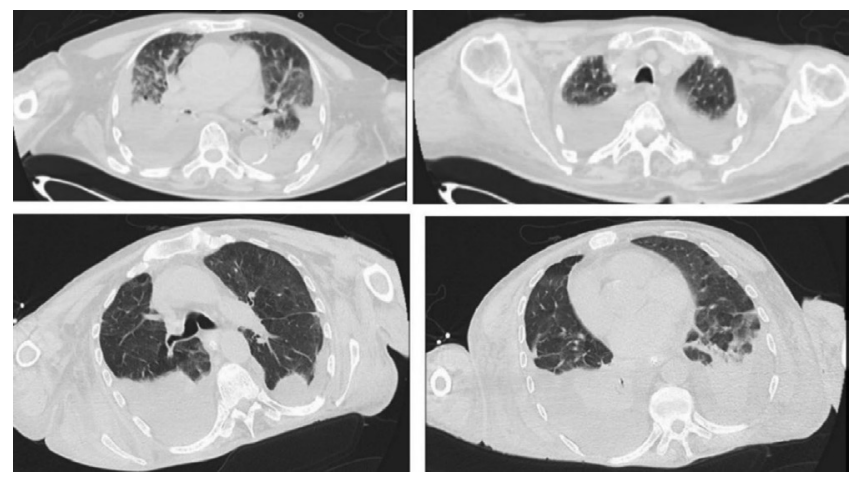

Figure 8. Computer tomography aspect of bronchopneumonia in a 96-year-old male patient with burns on 20\% TBSA

\section{Bloodstream infections ${ }^{26}$ :}

In order to diagnose a bloodstream infection, at least one of the following conditions must be present:

- The patient has two or more positive results on hemocultures for a certain pathogen agent or one positive result on hemoculture in association with sepsis, or

- The patient has a mutual skin contaminating pathogen harvested from two or more hemocultures on different occasions, associated with sepsis.

The bloodstream infection is regarded as:

- Primary: the same pathogen has not been harvested before at a different situs;

- Secondary: the same pathogen is harvested at another site;

- A catheter-linked bloodstream infection: the patient presents with sepsis without other source of infection and the sepsis signs disappear during one day after the catheter has been removed.

\section{Sepsis diagnosis in burned patients (Figure 9) ${ }^{26,37}$}

- Use of biomarkers( like Procalcitonin) is useful to discriminate between the septic from the non-septic burn patients 9 .

\section{II.C. TREATMENT OF INFECTIOUS COMPLICATIONS \\ Principles of systemic antibiotic treatment (Figure 10) $)^{8,9,26}$.}

\section{Burn wound infection treatment \\ (Figure 11) $)^{8,26,29-31}$ :}

- Sample bacteriological secretions at hospital admission-can guide the antibiotherapy if specific pathogens are encountered; 


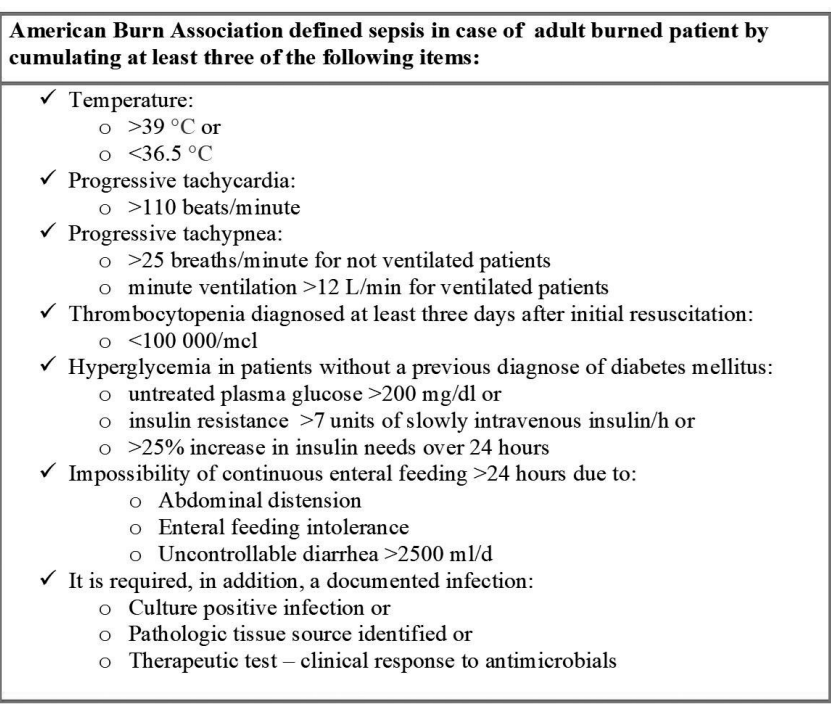

Figure 9. Criteria for sepsis definition in adult burned patient

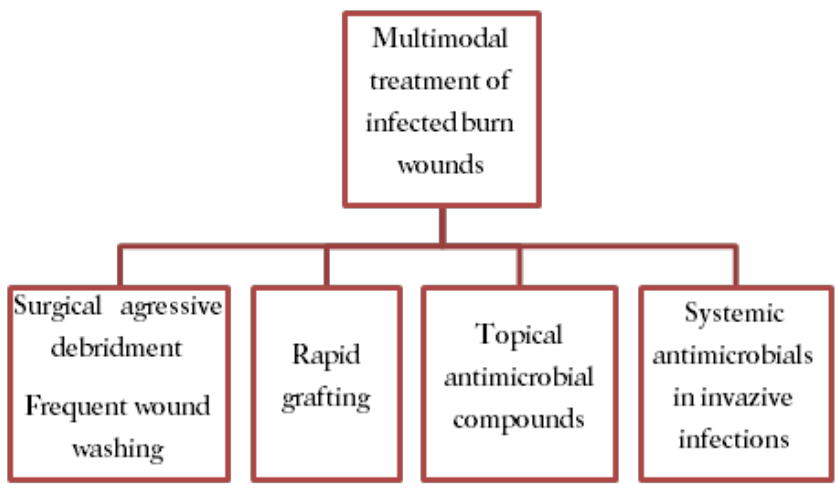

Figure 11. Therapeutic approach for burn wound infection

- For clean wound and superficial infection or colonization: apply Silver Sulfadiazine, no systemic therapy needed; Cerium-nitrate sulfadiazine can be applied on burn eschar and early surgical excision is mandatory for deep burns;

- Gram negative infection: topical Mafenide Acetate is recommended +/- systemic therapy and surgical excision of the wound;

- Burn wound invasive infection: topical Silver Sulfadiazine, systemic antimicrobial therapy, surgical excision(often fascial excision);

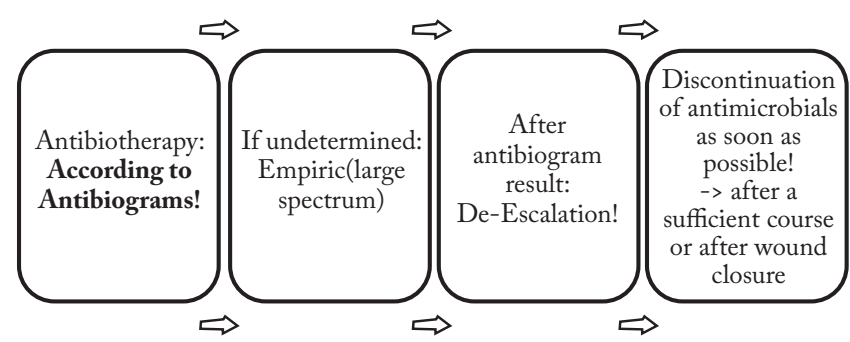

Figure 10. Antibiotic treatment in burn patients

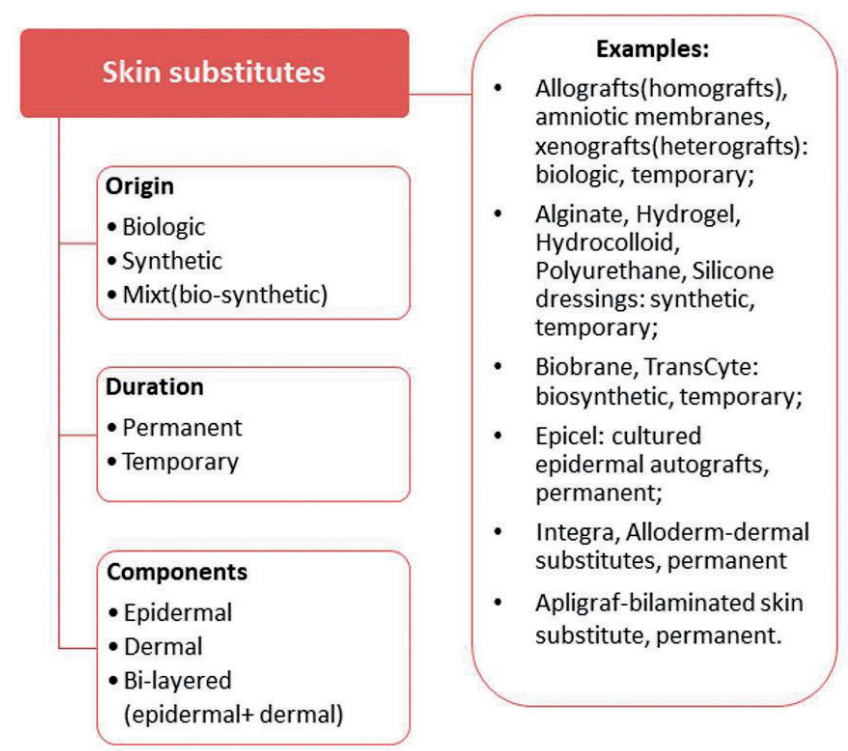

Figure 12. Classification of skin substitutes $\mathrm{s}^{30,40,41}$

- Local fungal infection: topical Nystatin and surgical excision are needed, without systemic therapy, invasive forms are exceptions of the rule and need enteral/parenteral antifungal medication;

- Viral: topical antivirals +systemic antiviral therapy in severe cases.

$\underline{\text { Skin autograft }=\text { Gold standard for burn wound }}$ coverage!

If autografts are not available, the use of skin substitutes is required (Figure 12). 
Topical agents adequate for burn wound care are presented in Table $1^{26,39,40}$.

\begin{tabular}{|c|c|c|}
\hline CLASS & TOPIC & CHARACTERISTICS \\
\hline \multirow{3}{*}{ ANTISEPTICS } & $\begin{array}{l}\text { Full-strength Dakin's Solution }(0.5 \% \\
\mathrm{NaOCl})\end{array}$ & $\begin{array}{l}\text { Broad-spectrum+Biofilm } \\
\text { Side effect: Hyponatremia }\end{array}$ \\
\hline & $\begin{array}{l}\text { 1/20th Buffered Dakin's Solution } \\
(0.025 \% \mathrm{NaOCl})\end{array}$ & Broad-spectrum + Biofilm \\
\hline & Hypochlorous acid & Broad-spectrum+Biofilm \\
\hline \multirow{7}{*}{ ELEMENTALS } & Povidone-Iodine(Betadine) & Broad-spectrum \\
\hline & Liposomal Iodine (Repithel) & $\begin{array}{l}\text { Unites the microbicidal role of the antiseptic substance with } \\
\text { the tolerability and absence of immunogenicity of liposomes; in } \\
\text { addition, liposomes provide a moist molecular film. } \\
\text { Pronounced positive effect of Repithel in burns in smokers }\end{array}$ \\
\hline & Silver Nitrate $0.5 \%$ & $\begin{array}{l}\text { Broad-spectrum } \\
\text { Side effect: Electrolyte inequity }\end{array}$ \\
\hline & Silver Sulfadiazine & $\begin{array}{l}\text { Broad-spectrum } \\
\text { Side effect: Leukopenia }\end{array}$ \\
\hline & Silver Releasing Dressings & $\begin{array}{l}\text { Broad-spectrum } \\
\text { Limited toxicity }\end{array}$ \\
\hline & Silver-impregnated biological material & $\begin{array}{l}\text { The includement of silver into amniotic based membrane adds a } \\
\text { different dimension to the proliferation of silver products. }\end{array}$ \\
\hline & Cerium nitrate SSD & $\begin{array}{l}\text { Cerium nitrate binds to and then denatures the lipid protein } \\
\text { complex produced by burn injuries which causes immunosupres- } \\
\text { sion, thereby preventing this process }\end{array}$ \\
\hline \multirow{9}{*}{ ANTI-MICROBIALS } & Mafenide acetate & $\begin{array}{l}\text { Broad-spectrum } \\
\text { Side effect: Metabolic acidosis }\end{array}$ \\
\hline & Gentamicin sulfate & Broad-spectrum \\
\hline & Nitrofurazone & Broad-spectrum, NO Pseudomonas \\
\hline & Nystatin $100000 \mathrm{U} / \mathrm{g}$ & Weak Antifungal \\
\hline & Nystatin $6000000 \mathrm{U} / \mathrm{g}$ & Strong Antifungal \\
\hline & Bacitracin & $\begin{array}{l}\text { Broad-spectrum } \\
\text { A good alternative for patients allergic to silver sulfadiazine }\end{array}$ \\
\hline & Mupirocin & Potent inhibitor of Gram-positive skin flora \\
\hline & Neosporin & $\begin{array}{l}\text { Broad-spectrum } \\
\text { Contains three different antibiotics: bacitracin, neomycin, and } \\
\text { polymyxin B }\end{array}$ \\
\hline & Polymyxin B & $\begin{array}{l}\text { Simple, basic peptide antibiotic } \\
\text { With bacitracin, polymyxin B encourages healing by containing } \\
\text { surface bacteria }\end{array}$ \\
\hline
\end{tabular}

Table 1. Characterics of topical agents used for burn injuries 
Below we present a series of images of two clinical cases illustrative for the pathology under discussion (Figures 13 and 14).

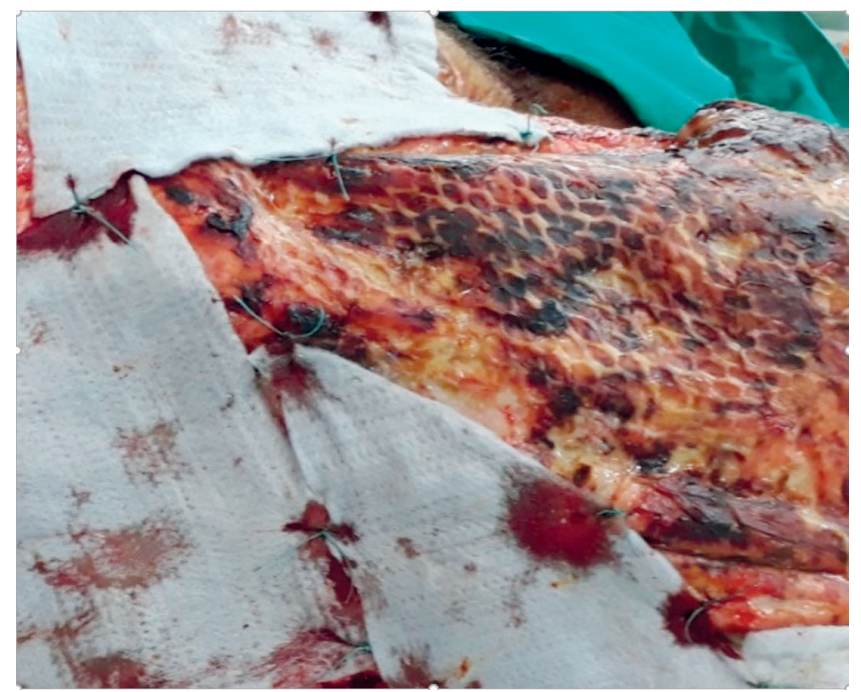

Figure 13. Use of Aquacel Ag dressings adjacent to an excised and grafted burn wound
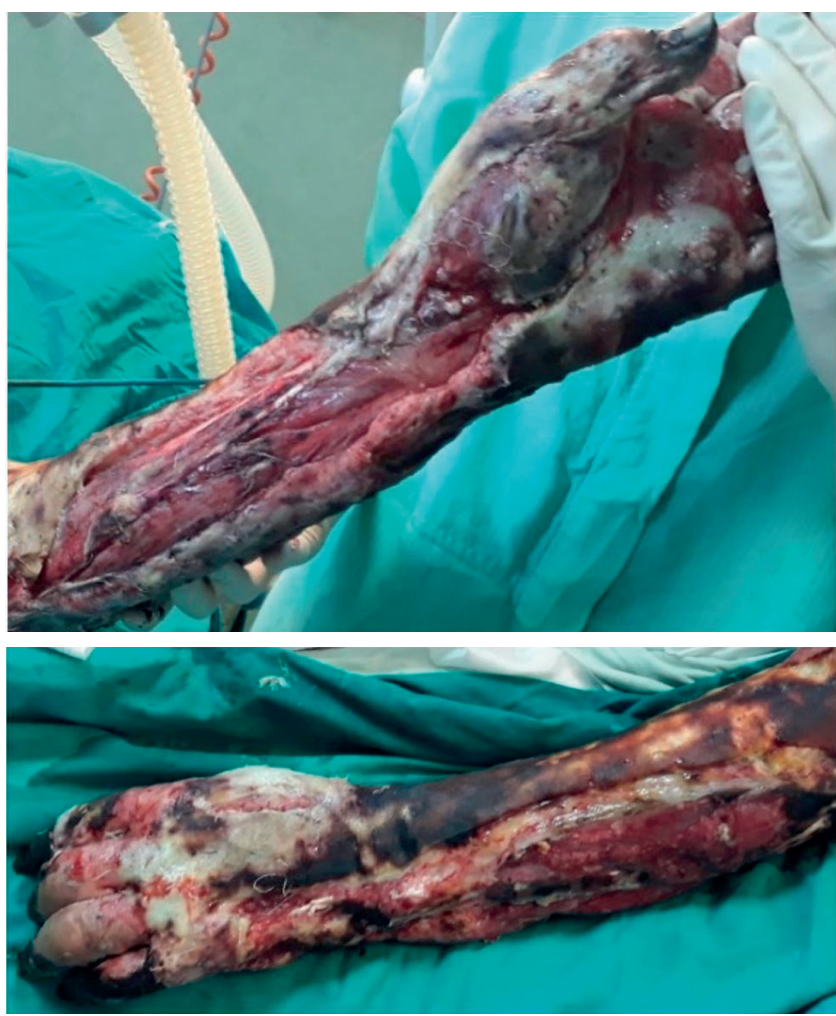

Figure 14. In a 64 year old male patient with extensive deep burns, serial excision and skin grafting was performed in the left upper limb but the evolution was unfavorable, with progresive necrosis, lysis of skin grafts and occurrence of infectious complication(Acinetobacter spp and Betalactamase-producing Pseudomonas aeruginosa) requiring upper limb amputation

\section{Ocular infections treatment ${ }^{34-36}$ :}

- Serial evaluation of the patient by the ophthalmologist who conduct the treatment;

- Continuous protective measures to maintain globe coverage, intraocular application of artificial tears;

- Topical antibiotics;

- Temporary tarsorrhaphy for lagophthalmos when eyelids present deep burns;

- Use of conjunctival flaps coverage of the ocular globe;

- Excision of the palpebral and orbital third degree burns and skin grafting to prevent further complications;

- Extreme destruction of the ocular globe may require enucleation.

Figure 15 present two clinical cases of burned patients with ocular infectious complications requiring specific treatment.

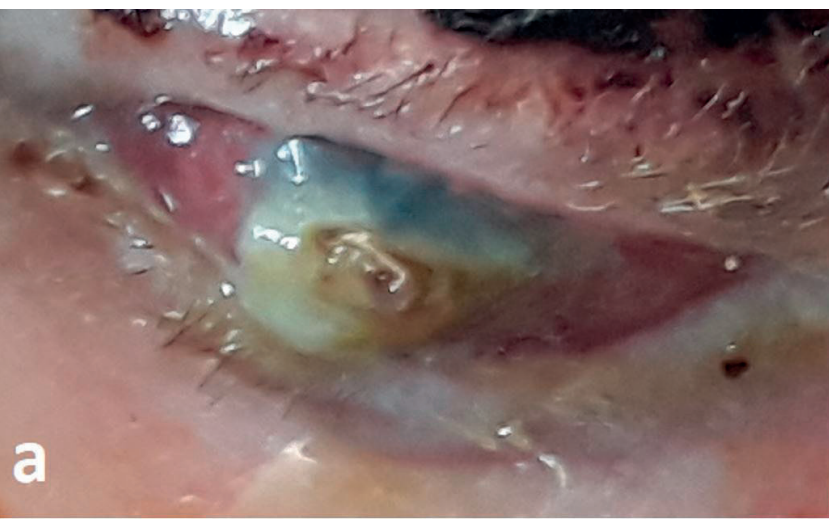

Figure 15. (a) A 62-year-old female burnt patient developed corneal abscess with iris perforation and herniation; microbiological testing revealed Pseudomonas aeruginosa as infective agent; a functional suture and tarsorraphy were performed and topical antibiotics were applied with favorable local response

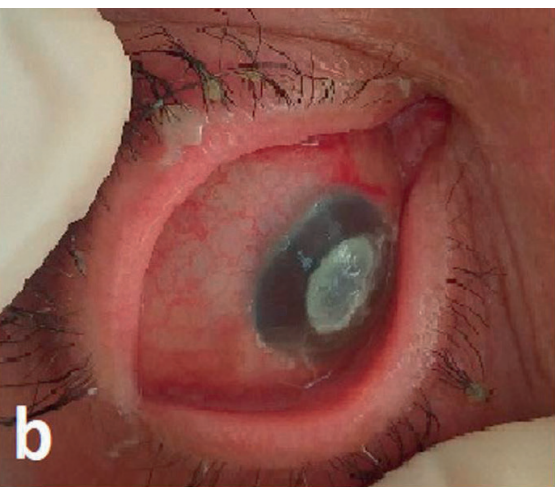

(b) A 60 year old severely burnt patient with long intubation and mechanical ventilation period developed corneal ulcer with hypopyon at 8 weeks after the admission; microbiologic tests determined multidrug resistant Pseudomonas aeruginosa, with sensitivity only for Colistin and Amikacin; topical colistin treatment was applied with remision of infectious process 


\section{Chondritis $^{26}$}

- topical application of Mafenide Acetate cream;

- directed antibiotic therapy;

- incision and abscess drainage, subsequently frequent lavage;

- aggressive surgical debridement is mandatory (Figure 16).
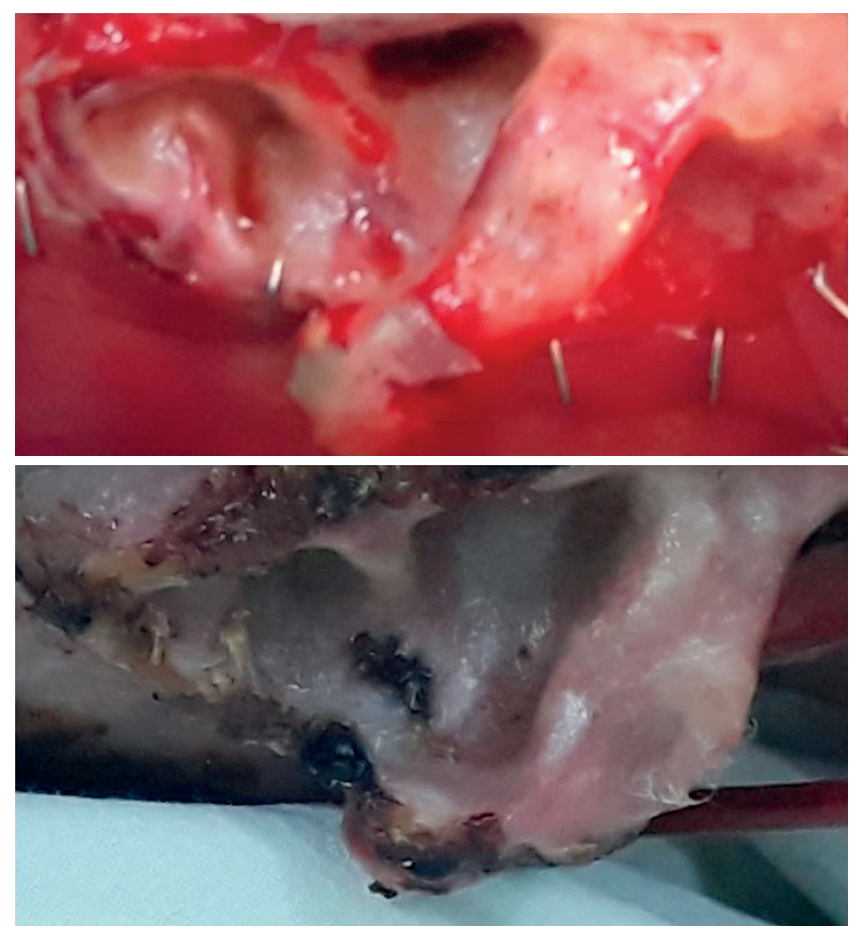

Figure 16. Deep auricle burns determining necrosis, imposing partial pavilion amputation

\section{Respiratory infections in burned patient ${ }^{8,26,42,43}$ :}

- Clinical and imagistic diagnosis is made and confirmed with tracheal or bronchial cultures;

- Broad spectrum antibiotherapy initially, then guided after antibiogram results;

- Ventilator support to help the patient oxigenate and ventilate;

- Agressive respiratory nursing;

- Therapeutic bronchoscopy;

- Tracheostomy performing if indicated;

- Clinical and imagistic monitoring with antimicrobial discontinuation when the condition is resolved.

\section{Urinary infections in burned patients s, $^{8,26}$}

- Positive urine cultures: initiation of empirical antibiotic, adjust after antibiogram results;
- Remove/change of urinary catheter;

- In case of high resistant bacteria, intermittent catheterization is recommended in addition to antimicrobials according to resistance profile;

- Microbiologic monitoring.

\section{Gastrointestinal infections ${ }^{8,26,44}$}

Digestive infections-antibiotherapy according to the results of fecal culture;

- Clostridium difficile infection:

- Oral or IV Metronidazole;

- Oral Vancomycin;

- IV antibiotics in severe forms;

- Severe complications include toxic megacolon or intestinal perforation treated surgically by: -either ileostomy in addition to subtotal or total colectomy with end ileostomy;

- or ileostomy and vancomycin colon lavage, the latter with less morbidity and mortality;

- Recurrent infections: above mentioned antibiotics, fidaxomicin, fecal microbiota transplant.

\section{REHABILITATION PHASE}

(Patient recovery part, extends beyond hospitalization, reintegration into society) ${ }^{1}$

- Essential to both physical and emotional healing;

- Multidisciplinary long-term follow up;

- Fragile patient with persistent immunosuppressive status: Avoid infectious exposure!

- Systemic support, metabolic recovery;

- Burn scars adequate treatment.

\section{DISCUSSIONS}

Burns are one of the most frequent and overwhelming types of trauma. Even though the numbers of burn injuries have shrunk in developed countries, the prevalence of burn injuries is still high in the rest of the world, with almost $90 \%$ of burns appear in low- and medium developed countries. The WHO evaluates that eleven million burn injuries of all types take place each year worldwide, 180000 of which are deadly ${ }^{1,45}$.

The survival rates for burn victims have highly increased in the last decades due to advances in modern medical treatment in specialized burn units. Better results for severely burned patients have been associated with therapy development in fluid resuscitation, nutritional base, pulmonary care, burn wound care and infection control practices. Patients with serious burn 
injury necessitate instant specialized treatment in order to diminish morbidity and mortality ${ }^{8}$.

It is generally indicated to transport the severely burnt patients to specialized centers as soon as possible, for proper treatment. The studies conducted particularly in the US and Canada reveal that the prognostic for the burnt patients initially admitted to non-specialized centers is generally much more severe than for the patients brought directly to burn centers ${ }^{46,47}$.

It is also very important that the admission in the burn unit is performed as fast as possible, in the first hours from the burn injury so that the patient benefits from proper fluid resuscitation. The traumatic shock is a combination between the hypovolaemic and cellular shock, consisting of specific microvascular and hemodynamic modifications. The main goal of fluid adminstration in burn lesions refers to keeping and restoring the tissue perfusion and ischemia prevention, reducing the systemic imbalances produced by the acute skin barrier distruption ${ }^{8,22}$.

Despite the advances in burns understanding, mortality continues to be high, especially due to infection, cardiopulmonary and multiple systems organ failure. The most important factors involved in patients prognostic are age, size and depth of burn, inhalation injury ${ }^{1}$.

An important aspect is the identification of patients who present the greatest risk of developing complications through the burn stages.

Lundgren et al. have conducted a study which reveals that the patients' age, unrelated to previous associated pathologies, together with the inhalation lesions and TBSA affected are the most important factors to evaluate the risk of mortality while the patient is hospitalized after the burn lesion. The depth of the burn, particularly the existence of a third-degree burn represents a highly important parameter that influences the burn severity ${ }^{48,49}$.

Overall incidence of infection is heavily dependent on the size of the patient's total body surface area (TBSA) burn. A threshold of 30\% TBSA was found out to be significant, anything below this percentage correlates to a low incidence percentage, mostly associated with invasive maneuvers and usage of devices. Incidence dramatically increases above this threshold, being in direct proportion relationship as burn wound size increases. This applies to pneumonia, urinary tract infections, gastrointestinal tract infection, as well as bloodstream infection ${ }^{50}$. Extensive burn injuries involving more than $40 \%$ TBSA have high mortality rate, $75 \%$ of deaths in those patients are determined by septic complications ${ }^{8}$.

The inhalation injury is normally related to a high morbidity and mortality rate being actually considered an independent risk factor despite the clear advancement in diagnostic, insuring the ventilation support and the patients' treatment that have caused the survival rate to rise in some centers ${ }^{51,52}$.

Severely burnt patients with significant inhalation injury benefit from an early tracheostomy because they require multiple surgical interventions and prolonged ventilation. Tracheostomy facilitates ventilator weaning by diminishing dead space, airway resistance, breathing effort and the sedation necessity. With a tracheostomy in place, there is a shorter and more accessible airway, the cough process and suctioning seem to be more effective, patient is more comfortable, with a quicker capability to speak. Mainly, tracheostomy seems to be linked with smaller risk of ventilator-related pneumonia, reduced mortality and shorter hospital stay as well as intensive care unit admission period compared to orotracheal intubation ${ }^{53-55}$.

The main challenges in burn treatment in the acute phase involve maintaining the vital parameters, proper treatment of burn injuries and severe complications profilaxy, particularly the infections ${ }^{29}$.

Hypermetabolism leads to multiple organ deficiency through intense catabolic processes, which cause the protein use not only in the muscle, but also in mostly all the other organs. Jeschke shows in his study that hypermetabolism, organ functions and surviving are closely linked to one another. The hypermetabolic reaction in burns is highly important and very complex, being activated and supported by hormonal releases produced in stress situations and inflammation. When this reaction is initiated, the metabolic rate is still raised and it associates an alteration of the glucose, lipids and aminoacids metabolism ${ }^{56,57}$.

Excision and early grafting of the burn lesions has probably been the only and highest progress in the burn therapy in last couple of decades. This has led to a significant reduction of basal energy necessity and thus, an ulterior improvement of the mortality rate has been remarked. The study conducted by Jeschke has concluded that burn injuries must quickly be excised, and the resulting defects should be covered with autologous skin grafts or skin substitutes. This would reduce the inflammatory reaction, as well as stress induced by the burn lesions, which would finally lead to drop of hypermetabolism ${ }^{57,58}$. 
Autografting represents the gold standard in the surgical treatment of a burnt patient. However, in most cases the autografts are not available, therefore the skin substitutes remain the only solution. From this point of view, the existence of an accesible functional skin graft bank is an important requirement ${ }^{59}$.

Following severe burns, the hypercatabolic reaction lasts long while after the acute phase. Along with early excision-grafting, thermoregulation and adequate nutrition play an important part in diminishing the hypermetabolic reaction in the acute phase. The high metabolic rate, a high protein and muscle catabolism have been noticed in some patients even for years after the accident ${ }^{60}$.

Due to the metabolic reaction in burn injuries, it is essential to establish an adequate nutritional support for wound healing, complications prophilaxy, and implicit for survival ${ }^{61}$.

Enteral nutrition is required for the intestinal tract support and for systemic nutrients administration, being associated with improving the immunologic and absorption roles of the enteral mucosa, maintaining motility, lowering the bacterial translocation and thus improving the survival rate ${ }^{62}$.

One of the main effects of the early enteral nutrition consists of metabolic modulation, with the reduction of the catabolic reaction related to burn injuries. The comparative studies have revealed that, by comparison to the parenteral nutrition, the enteral nutrition is well tolerated and linked to a lower septic morbidity, costs and hospitalization length ${ }^{63}$.

A recent concept seen in the therapy of the critical patient, including severe burnt patients, is the immunonutrition. This is defined by the possibility of modulating the immune system's activity through specific nutrients: arginine, omega 3 fatty acids, glutamine and nucleotides have the purpose of modulating the host's reaction and therefore have the role of improving the immunity ${ }^{64,65}$.

Selective decontamination of the digestive tract is also a strategy for preventing infections in the burnt patients. This determines a better infection control (like for bloodstream infections and pneumonia) and thus, a lower rate of multiple organ deficiency and mortality, also with a good control of resistance ${ }^{66,67}$.

Infections are the most sever and the most frequent complication in severely burned patients and requires adequate diagnosis and treatment ${ }^{8,38}$. Infection pre- vention represents a key element in burn care management $^{68}$.

As general rules, within burn unit, the patient needs to be isolated, the medical personnel must wear special equipment to prevent wound contaminations and it is advisable to start systemic antibiotic therapy as late as possible, to prevent antibiotic resistance. This last statement highlights the hardest decision in terms of infection control regarding the burned patient $t^{9,10}$.

Because the endogenous flora is the most common source for infections in burn patients, it is recommended to sample bacteriological secretions at hospital admission. This type of screening should include sampling the inguinal and axillary region bilaterally, as well as nasal, pharyngeal and tracheal secretions in order to identify existing pathogens with further invasive potential ${ }^{8,16,38}$.

The culture swabs are helpful but have a use limitation because they can't make the difference between infection and colonization and are relevant only for the area where the swab has been taken. These issues can be solved by harvesting multiple tissue biopsies that may reveal important quantitative differences in different $\operatorname{areas}^{69,70}$.

Although the quantitative cultures are more expensive, the correlation between bacteriologic quantification and histological diagnostics in burn wounds has been proven very accurate even after the antisepsis of the sites. The histological evaluation can be used to verify the invasive bacterial infection and if result is positive, systemic antibiotherapy is required, as well as deep wound excision ${ }^{8,26}$. Sensibility to the available antibiotics, both topic and systemic, will decide the therapy to be followed in these cases. If resistant organisms are present, testing the antibiotics synergy is recommendable. Therefore, the final diagnostic in burn wound infections and systemic antibiotherapy guidance are determined by bacterial culture results ${ }^{26}$.

Previous studies have revealed that the graft survival rate is only $19 \%$ if the burn wound biopsy result shows more than $10^{5}$ organsims/tissue gram, while a lower bacterial population is linked to a $94 \%$ survival rate of the skin grafts ${ }^{26}$.

Treatment should be instantly initiated when invasive burn wound infection occurs and it involves aggressive surgical treatment, enhanced by systemic and topic antibiotherapy. If there are no initial culture results, an empirical large spectrum antibiotherapy is applied against Gram positive/negative bacteria and 
fungi until the final cultures processing. Surgical debridement must be aggressive and include the excision of all necrotic and infected tissues, including fascia and muscle if necessary. Complete immediate coverage of the surgically processed burn wound is not always indicated, because dressing changes and hydrotherapy can be required to lower the bacterial load, permitting further grafting. When the tissues have already been excised or there is a life-threatening infection, amputation of the burnt limb may be indicated. Topic antibiotherapy and intense local hygiene are mandatory after excision to suppress the bacterial development. However, the optimal treatment is the prevention of any kind of infection ${ }^{8,30,32,71}$.

Pneumonia has turned into a more outstanding cause of high morbidity and mortality, as the incidence of invasive burn wound infections decreases. It is a more important problem for adults with previous lung disease or in case of airway burn lesion ${ }^{8,9,43}$.

Pulmonary complications are frequent in burn $\mathrm{pa}^{-}$ tients with inhalation lung lesions. Burnt patients with severe inhalation injury necessitating a lengthy intubation period are also exposed to the development of ventilator-associated pneumonia, generally caused by nosocomial pathogens that are more antibiotic resistant ${ }^{8,72}$.

Burn patients may also have pulmonary complications even when the lungs have not suffered direct burn injuries. Atelectasis and hypostatic pneumonia are frequent because of the hyperventilation and reduced lung expansion that is observed in patients with large burn surfaces(more than 30\% TBSA); circumferential eschar development may determine chest wall restriction requiring escharotomies ${ }^{8}$. Burn patients also have a significant risk of recurrent aspiration episodes, and respiratory therapy with frequent aspiration of upper airway secretions and sputum expectoration are crucial to supporting pulmonary function ${ }^{8}$.

Even though hematogenous pneumonia is a much less encountered complication in burn patients today than in previous decades, it is however a severe complication that may be prevented. Blood cultures should be harvested before to the start of antibiotic therapy in burn patients with fever and suspected pneumonia in order to diagnostic bacteremia ${ }^{8,38}$.

Emerging antimicrobial resistance tendency in burn wound germs represent a significant therapeutic difficulty. The inappropriate use of antimicrobial compounds determines negative outcomes for burnt patient with further development of resistant germs and higher cost for the burn unit. Antibiotic-resistant organisms such as Methicillin-resistant Staphylococcus aureus (MRSA), vancomycin-resistant Enterococcus species, multi-resistant gram-negative bacteria, including Pseudomonas aeruginosa, Acinetobacter spp., and different members of the Enterobacteriaceae family, have been linked to burn wound infections and other anatomic location in patients with severe burn injury, seldom in the form of nosocomial flare-ups. Some patients have a series of risk factors for acquiring of an antibiotic-resistant pathogen: advanced age, prior hospitalization, antibiotic treatment administered before the progress of infection, long period of hospitalization, invasive maneuvers, comatose state $e^{8,26,38}$.

Strict infection control proceedings (such as physical confinement in a private room, utilization of gowns and gloves during patient direct contact and good hand hygiene before and after each patient visit) and adequate empirical antimicrobial treatment are fundamental to help in decreasing the incidence of infections caused antibiotic resistant bacteria ${ }^{8,9,68}$.

Awareness of the local antibiogram specific to each burn unit, which may differ from other hospital departments, is highly important for the improvement of empiric antibiotic treatment. Simultaneously, promoting of an antimicrobial stewardship program is mandatory, to reduce antibiotics administration in patients who do not necessarily need them and avoid further infection with multi-drug resistant bacteria ${ }^{9}$.

\section{CONCLUSION}

Infection control in the burned patient is a dynamic process, comprising the entire period of the patient's hospitalization and addressing a multitude of factors related to burn unit care and patient characteristics. It is mandatory to identify the patients with high risk of developing complications in order to ensure prompt diagnostic and therapeutic measures, therefore decreasing morbidity and mortality. The most important therapeutic goal for a severe burnt patient consists of the quick achievement of a satisfying immunity, while preventing infectious complications. This goal can be helped by adequate systemic supportive measures, early enteral nutrition, early complete excision of deep burns and skin grafting, avoidance of large spectrum empirical antibiotic prophylaxis, antibiogram guided treatment, including de-escalation decision and constant reevaluation, as well as limitation of invasive catheterization. 
Compliance with ethics requirements: The authors declare no conflict of interest regarding this article. The authors declare that all the procedures and experiments of this study respect the ethical standards in the Hel- sinki Declaration of 1975, as revised in 2008(5), as well as the national law. Informed consent was obtained from all the patients included in the study.

\section{References:}

1. Jeschke MG, van Baar ME, Choudhry MA, Chung KK, Gibran NS, Logsetty S. Burn injury. Nat Rev Dis Primers. 2020;6(1):11. Published 2020 Feb 13. doi:10.1038/s41572-020-0145-5.

2. Brusselaers N, Monstrey S, Vogelaers D, Hoste E, Blot S. Severe burn injury in Europe: a systematic review of the incidence, etiology, morbidity, and mortality. Crit Care. 2010;14(5):R188. doi:10.1186/cc9300.

3. Al-Mousawi AM, Mecott-Rivera GA, Jeschke MG, Herndon DN Burn teams and burn centers: the importance of a comprehensive team approach to burn care. Clin Plast Surg. 2009;36(4):547554. doi:10.1016/j.cps.2009.05.015.

4. Burn Center Referral Criteria, American Burn Association, available on: https://ameriburn.org/public-resources/burn-center-referral-criteria

5. Snell JA, Loh N-HW, Mahambrey T, Shokrollahi K. Clinical review: The critical care management of the burn patient. Critical Care. 2013;17(5):241. doi:10.1186/cc12706.

6. Bittner EA, Shank E, Woodson L, Martyn JAJ. Acute and Perioperative Care of the Burn-Injured Patient. Anesthesiology. 2015;122(2):448-464.

7. Nielson CB, Duethman NC, Howard JM, Moncure M, Wood JG. Burns: Pathophysiology of Systemic Complications and Current Management. J Burn Care Res. 2017;38(1):e469-e481. doi:10.1097/BCR.0000000000000355.

8. Church D, Elsayed S, Reid O, Winston B, Lindsay R. Burn wound infections. Clin Microbiol Rev. 2006;19(2):403-434. doi:10.1128/ CMR.19.2.403-434.2006

9. Lachiewicz AM, Hauck CG, Weber DJ, Cairns BA, van Duin D. Bacterial Infections After Burn Injuries: Impact of Multidrug Resistance. Clin Infect Dis. 2017;65(12):2130-2136. doi:10.1093/cid/ cix682.

10. Coban YK. Infection control in severely burned patients. World J Crit Care Med. 2012;1(4):94-101. Published 2012 Aug 4 doi:10.5492/wjccm.v1.i4.94.

11. The ABCDE and SAMPLE History Approach Basic Emergency Care Course, World Health Organization, available on https:// www.who.int/emergencycare/publications/BEC_ABCDE_Approach_2018a.pdf

12. Thim T, Krarup NH, Grove EL, Rohde CV, Løfgren B. Initial assessment and treatment with the Airway, Breathing, Circulation, Disability, Exposure (ABCDE) approach. Int J Gen Med. 2012;5:117121. doi:10.2147/IJGM.S28478.

13. Hettiaratchy S, Papini R. Initial management of a major burn: I-overview. BMJ. 2004;328(7455):1555-1557. doi:10.1136/ bmj.328.7455.1555.

14. Schaefer TJ, Nunez Lopez O. Burn Resuscitation And Management. [Updated 2020 Jul 31]. In: StatPearls [Internet]. Treasure Island (FL): StatPearls Publishing; 2021

15. Mlcak RP, Buffalo MC, Jimenez CJ. Prehospital Management Transportation, and Emergency Care, Chapter in Herndon DN(Ed.) Total Burn Care (Fifth Edition). Elsevier, 2018. Pages 58-65.e1.

16. Protocol of admission and care of severely burned patient in the first 72 hours post-injury, Emergency Clinical Hospital of Bucharest, Bucharest 2016

17. Brownson EG, Pham TN, Chung KK. How to Recognize a Failed Burn Resuscitation. Crit Care Clin. 2016 Oct;32(4):567-75. doi: 10.1016/j.ccc.2016.06.006

18. Knowlin L, Stanford L, Moore D, Cairns B, Charles A. The Measured Effect Magnitude of Co-Morbidities on Burn injury Mortality. Burns : journal of the International Society for Burn Injuries. 2016:42(7):1433-1438.

19. Colohan SM. Predicting prognosis in thermal burns with associated inhalational injury: a systematic review of prognostic factors in adult burn victims. J Burn Care Res. 2010;31(4):529-39.

20. Hussain A, Dunn KW. Predicting length of stay in thermal burns: a systematic review of prognostic factors. Burns. 2013;39(7):1331-40.

21. Santaniello JM, Luchette FA, Esposito TJ, Gunawan H, Reed RL, Davis KA, Gamelli RL. Ten year experience of burn, trauma, and combined burn/trauma injuries comparing outcomes. J Trauma. 2004;57(4):696-700

22. Guilabert P, Usúa G, Martín N, Abarca L, Barret JP, Colomina MJ Fluid resuscitation management in patients with burns: update. Br J Anaesth. 2016 Sep;1 17(3):284-96. doi: 10.1093/bja/aew266. PMID: 27543523.

23. Cancio L, Bohanon F, Kramer G. Burn resuscitation, Chapter in Herndon DN(Ed.) Total Burn Care (Fifth Edition). 2018 Elsevier, pages 77-86.

24. Dries DJ, Marini JJ. Management of Critical Burn Injuries: Recent Developments. Korean J Crit Care Med. 2017;32(1):9-21. doi:10.4266/kjccm.2016.00969.

25. Alharbi Z, Piatkowski A, Dembinski R, Reckort S, Grieb G, Kauczok J, Pallua N. Treatment of burns in the first 24 hours: simple and practical guide by answering 10 questions in a step-by-step form. World J Emerg Surg. 2012 May 14;7(1):13. doi: 10.1186/17497922-7-13. PMID: 22583548; PMCID: PMC3506488.

26. Cambiaso-Daniel J, Gallagher JJ, Norbury WB, FinnertyCC, Herndon DN, Culnan DM. Treatment of Infection in Burn Patients, Chapter in Herndon DN(Ed.) Total Burn Care (Fifth Edition). Elsevier, 2018. pages 93-113.e4

27. Culnan DM, Capek KD, Sheridan RL. Etiology and Prevention of Multisystem Organ Failure. Chapter in Herndon DN(Ed.) Total Burn Care (Fifth Edition). 2018 Elsevier, pages 307-317.e5

28. Greenhalgh DG. Management of Burns. N Engl J Med. 2019 Jun 13;380(24):2349-2359. doi: 10.1056/NEJMra1807442. PMID: 31189038

29. Rowan MP, Cancio LC, Elster EA, et al. Burn wound healing and treatment: review and advancements. Crit Care. 2015;19:243. Published 2015 Jun 12. doi:10.1186/s13054-015-0961-2.

30. Andrei MC, Grosu-Bularda A, Vermesan $O$ et al. Surgical Treatment in Acute Phase of Severe Burns - a Comprehensive Approach. Modern Medicine .2018, Vol. 25, No. 1.

31. Gacto-Sanchez P. Surgical treatment and management of the severely burn patient: Review and update. Med Intensiva. 2017 Aug-Sep;41(6):356-364. English, Spanish. doi: 10.1016/j.medin.2017.02.008. Epub 2017 Apr 26. PMID: 28456441.

32. Browning JA, Cindass R. Burn Debridement, Grafting, and Reconstruction. [Updated 2020 Nov 24]. In: StatPearls [Internet]. Treasure Island (FL): StatPearls Publishing; 2021. 
Infectious Complications in Severely Burned Adult Patients-Diagnostic and Therapeutic Algorithm

33. Goel J, Nizamoglu M, Tan A, Gerrish H, Cranmer K, El-Muttardi N, Barnes D, Dziewulski P. A prospective study comparing the FLIR ONE with laser Doppler imaging in the assessment of burn depth by a tertiary burns unit in the United Kingdom. Scars Burn Heal.

34. Fitzgerald O'Connor E, Frew Q, Din A, Pleat J, Ashraff S, GhaziNouri S, El-Muttardi N, Philp B, Dziewulski P. Periorbital burns - a 6 year review of management and outcome. Burns. 2015;41(3):616-23.

35. Sarabahi S, Kanchana K. Management of ocular and periocular burns. Indian J Burns 2014;22:22-32.

36. Grosu-Bularda A, Andrei MC, Mladin AD, Ionescu Sanda M, Dringa MM, Lunca DC, Lascar I, Teodoreanu RN. Periorbital lesions in severely burned patients. Rom J Ophthalmol. 2019 JanMar;63(1):38-55. PMID: 31198897 ; PMCID: PMC6531771.

37. Greenhalgh DG, Saffle JR, Holmes JH 4th, Gamelli RL, Palmieri TL, Horton JW, Tompkins RG, Traber DL, Mozingo DW, Deitch EA, Goodwin CW, Herndon DN, Gallagher JJ, Sanford AP, Jeng JC, Ahrenholz DH, Neely AN, O'Mara MS, Wolf SE, Purdue GF, Garner WL, Yowler CJ, Latenser BA; American Burn Association Consensus Conference on Burn Sepsis and Infection Group. American Burn Association consensus conference to define sepsis and infection in burns. J Burn Care Res. 2007 Nov-Dec;28(6):776-90. doi: 10.1097/BCR.0b013e3181599bc9. PMID: 17925660.

38. Norbury W, Herndon DN, Tanksley J, Jeschke MG, Finnerty CC Infection in Burns. Surg Infect (Larchmt). 2016;17(2):250-255. doi:10.1089/sur.2013.134.

39. Rowley-Conwy G. Infection prevention and treatment in patients with major burn injuries. Nurs Stand. 2010;25:51-2. doi: 10.7748/ ns2010.10.25.7.51.c8053.

40. Dai T, Huang YY, Sharma SK, Hashmi JT, Kurup DB, Hamblin MR. Topical antimicrobials for burn wound infections. Recent Pat Antiinfect Drug Discov. 2010;5(2):124-151. doi:10.2174/157489110791233522.

41. Middelkoop E, Sheridan RL. Skin substitutes and "the next level", Chapter in Herndon DN(Editor). Total Burn Care (Fifth Edition), Elsevier, 2018.Pages 167-173.

42. Walker PF, Buehner MF, Wood LA, et al. Diagnosis and management of inhalation injury: an updated review. Crit Care. 2015;19:351. Published 2015 Oct 28. doi:10.1186/s13054-0151077-4

43. Weber J, McManus A; Nursing Committee of the International Society for Burn Injuries. Infection control in burn patients. Burns. 2004 Dec;30(8):A16-24. doi: 10.1016/j.burns.2004.08.003. PMID: 15555784

44. Lopez ON, Bohanon FJ,Radhakrishnan RS, Chung DH. Surgical Management of Complications of Burn Injury, Chapter in Herndon DN(Editor). Total Burn Care (Fifth Edition), Elsevier, 2018. Pages 386-395.

45. World Health Organization. Burns. Available on WHO https:// www.who.int/en/news-room/fact-sheets/detail/burns

46. Sheridan R, Weber J, Prelack K, Petras L, Lydon M, Tompkins $\mathrm{R}$. Early burn center transfer shortens the length of hospitalization and reduces complications in children with serious burn injuries. J Burn Care Rehabil. 1999 Sep-Oct;20(5):347-50. doi: 10.1097/00004630-199909000-00002. PMID: 10501318.

47. Klein MB, Nathens AB, Emerson D, Heimbach DM, Gibran NS. An analysis of the long-distance transport of burn patients to a regional burn center. J Burn Care Res. 2007 Jan-Feb;28(1):49-55 doi: 10.1097/BCR.0B013E31802C894B. PMID: 17211200.

48. Lundgren RS, Kramer CB, Rivara FP, et al. Influence of Comorbidities and Age on Outcome Following Burn Injury in Older Adults. Journal of burn care \& research : official publication of the American Burn Association. 2009;30(2):307-314.

49. Schaefer TJ, Tannan SC. Thermal Burns. [Updated 2020 Sep 18]
In: StatPearls [Internet]. Treasure Island (FL): StatPearls Publishing; 2021

50. Weber JM, Neely AN, Mayhall CG. Burns.Chapter in Carrico R, (Editor), APIC Text of Infection Control and Epidemiology 3rd edition, Washington D.C., APIC, 2009

51. El-Helbawy RH, Ghareeb FM. Inhalation injury as a prognostic factor for mortality in burn patients. Ann Burns Fire Disasters. 2011;24(2):82-88.

52. Klein MB, Goverman J, Hayden DL, Fagan SP, McDonald-Smith GP, Alexander AK, Gamelli RL, Gibran NS, Finnerty CC, Jeschke MG, Arnoldo B, Wispelwey B, Mindrinos MN, Xiao W, Honari SE, Mason PH, Schoenfeld DA, Herndon DN, Tompkins RG; Inflammation and Host Response to Injury, and Large-Scale Collaborative Research Program. Benchmarking outcomes in the critically injured burn patient. Ann Surg. 2014 May;259(5):833-41. doi: 10.1097/SLA.0000000000000438. PMID: 24722222; PMCID: PMC4283803.

53. Durbin CG Jr. Tracheostomy: why, when, and how? Respir Care. 2010; 55(8):1056-68.

54. Gravvanis Al, Tsoutsos DA, Iconomou TG, Papadopoulos SG. Percutaneous versus conventional tracheostomy in burned patients with inhalation injury. World J Surg 2005, 29:1571-1575.

55. Pierson DJ. Tracheostomy and weaning. Respir Care. 2005; 50(4):526-33.

56. Pereira C, Murphy K, Jeschke $M$, Herndon DN. Post burn muscle wasting and the effects of treatments. Int $\mathrm{J}$ Biochem Cell Biol. 2005 Oct;37(10):1948-61. doi: 10.1016/j.biocel.2005.05.009. PMID: 16109499.

57. Jeschke MG. Postburn Hypermetabolism: Past, Present, and Future. J Burn Care Res. 2016 Mar-Apr;37(2):86-96. doi: 10.1097/BCR.0000000000000265. PMID: 26132047; PMCID: PMC4691431.

58. Lee KC, Joory K, Moiemen NS. History of burns: The past, present and the future. Burns Trauma. 2014;2(4):169-180. Published 2014 Oct 25. doi:10.4103/2321-3868.143620.

59. Atiyeh BS, Gunn SW, Hayek SN. State of the art in burn treatment. World J Surg. 2005 Feb;29(2):131-48. doi: 10.1007/s00268-0041082-2. PMID: 15654666

60. Porter C, Tompkins RG, Finnerty CC, Sidossis LS, Suman OE, Herndon DN. The metabolic stress response to burn trauma: current understanding and therapies. Lancet. 2016;388(10052):14171426. doi:10.1016/S0140-6736(16)31469-6.

61. Price C. Nutrition: reducing the hypermetabolic response to thermal injury. Br J Nurs. 2018 Jun 28;27(12):661-670. doi: 10.12968/ bjon.2018.27.12.661. PMID: 29953277.

62. Schörghuber M, Fruhwald S. Effects of enteral nutrition on gastrointestinal function in patients who are critically ill. Lancet Gastroenterol Hepatol. 2018 Apr;3(4):281-287. doi: 10.1016/S24681253(18)30036-0. Epub 2018 Mar 7. PMID: 29533200

63. Ward N. Nutrition support to patients undergoing gastrointestinal surgery. Nutr J. 2003;2:18. Published 2003 Dec 1. doi:10.1186/1475-2891-2-18.

64. Kurmis R, Parker A, Greenwood J. The use of immunonutrition in burn injury care: where are we? J Burn Care Res. 2010 SepOct;31(5):677-91. doi: 10.1097/BCR.0b013e3181 eebf01. PMID: 20671563

65. Calder PC. Immunonutrition. BMJ. 2003 Jul 19;327(7407):1178. doi: 10.1136/bmj.327.7407.117. PMID: 12869428; PMCID: PMC1126497.

66. Silvestri L, van Saene HK. Selective decontamination of the digestive tract: an update of the evidence. HSR Proc Intensive Care Cardiovasc Anesth. 2012;4(1):21-29.

67. Aboelatta YA, Abd-Elsalam AM, Omar AH, Abdelaal MM, Farid AM. Selective digestive decontamination (SDD) as a tool in the man- 
agement of bacterial translocation following major burns. Ann Burns Fire Disasters. 2013 Dec 31;26(4):182-8. PMID: 24799847; PMCID: PMC3978589.

68. Rafla K, Tredget EE. Infection control in the burn unit. Burns. 2011 Feb;37(1):5-15. doi: 10.1016/j.burns.2009.06.198. Epub 2010 Jun 18. PMID: 20561750

69. Vural MK, Altoparlak U, Celebi D, Akcay MN. Comparison of surface swab and quantitative biopsy cultures dependent on isolated microorganisms from burn wounds. Eurasian $\mathrm{J}$ Med. 2013;45(1):34-38. doi:10.5152/eajm.2013.05.

70. Uppal SK, Ram S, Kwatra B, Garg S, Gupta R. Comparative evaluation of surface swab and quantitative full thickness wound biopsy culture in burn patients. Burns. 2007;33:460-3.
71. ISBI Practice Guidelines Committee; Steering Subcommittee; Advisory Subcommittee. ISBI Practice Guidelines for Burn Care. Burns. 2016 Aug;42(5):953-1021. doi: 10.1016/j. burns.2016.05.013. PMID: 27542292.

72. Huzar TF, Cross JM. Ventilator-associated pneumonia in burn patients: a cause or consequence of critical illness? Expert Rev Respir Med. 2011 Oct;5(5):663-73. doi: 10.1586/ers.11.61. PMID: 21955236. 